ARTIKEL

\title{
TRUST BUILDING PEDAGANG KAIN DAN PAKAIAN DI CIREBON
}

\author{
Moh. Dulkiah \\ UIN Sunan Gunung Djati, Bandung, West Java, Indonesia \\ moh.dulkiah@uinsgd.ac.id
}

\begin{abstract}
This writting describes about interaction between one trader to other trader. In the interaction, both of them have unique relation. In the fact, the relation among them is based on personal trust. This study use descriptive methode in qualitative approach. The result of study is the key to the success of a cooperation is strongly influenced by mutual trust that is raised by all parties involved. The sustainability of a cooperation is strongly influenced by the size of the degree of confidence (radius of trust) that is established among the parties involved. Cooperation will be easy to do and can last long if it builds a bigh value/ norm of trust. Conversely cooperation will be easily destroyed even not formed at all if in it has a value/norm of trust is low. Thus the high level of cooperation is very inhern with how much value/norm of trust formed between the parties involved in cooperation.
\end{abstract}

Keyword: Trust, Social Capital, Interaction.

\begin{abstract}
Abstrak
Tulisan ini menguraikan tentang interaksi antara satu pedagang dengan pedagang lainnya. Dalam interaksi, keduanya memiliki hubungan yang unik. Faktanya, hubungan di antara mereka didasarkan pada kepercayaan pribadi. Penelitian ini menggunakan metode deskriptif dengan pendekatan kualitatif. Hasil penelitian merupakan kunci keberhasilan suatu kerja sama sangat dipengaruhi oleh rasa saling percaya yang diangkat oleh semua pihak yang terlibat. Keberlanjutan kerja sama sangat dipengaruhi oleh ukuran tingkat kepercayaan (radius kepercayaan) yang didirikan di antara pihak-pihak yang terlibat. Kerjasama akan mudah dilakukan dan dapat bertahan lama jika membangun nilai/norma kepercayaan yang tinggi. Sebaliknya kerjasama akan mudah hancur bahkan tidak terbentuk sama sekali jika di dalamnya memiliki nilai/norma kepercayaan yang rendah. Dengan demikian tingkat kerjasama yang tinggi sangat berkaitan dengan seberapa besar nilai/norma kepercayaan yang terbentuk antara pihakpihak yang terlibat dalam kerja sama.
\end{abstract}

Kata Kunci: Kepercayaan, Modal Sosial, Interaksi.

\section{A. Pendahuluan}

Daya serap tenaga kerja sektor pertanian yang semakin menurun sebagai dampak dari involusi pertanian (Geertz, 1983) menyebabkan terjadinya peningkatan sektor-sektor lain di luar pertanian (off-farm employment). Salah satunya terlihat pada sektor perdagangan di pasar-pasar tradisional. Sektor per-dagangan dinilai cukup 
strategis dalam meningkatkan kehidupan ekonomi masyarakat dan sekaligus mengurangi jumlah angka peng-angguran yang mulai melonjak sejak terjadinya krisis moneter pada paruh kedua tahun 1997.

Perubahan sistem per-ekonomian dari sektor pertanian ke sektor perdagangan setidaknya dialami oleh masyarakat Tegal Gubug Cirebon. Sejak tahun 1967, mayoritas masyarakat Tegal Gubug mulai meninggalkan profesi sebagai petani dan beralih menjadi pedagang. Penyebab terjadinya perubahan ini adalah karena daya serap sektor pertanian tidak sebanding dengan populasi penduduk yang terus mengalami peningkatan sehingga memungkinkan bagi anggota masyarakat yang tidak terserap dalam sektor ini mencari alternatif penghasilan lain. Di samping itu, banyak masyarakat menilai bahwa ternyata sektor perdagangan mem-berikan keuntungan yang lebih besar dibandingkan sektor pertanian.

Perdagangan kain dan pakaian di Tegal Gubug Cirebon dari tahun ke tahun mengalami peningkatan. Saat ini pun Pasar Induk Sandang Tegal Gubug dianggap sebagai pasar sandang terbesar di Jawa Barat dan paling ramai dikunjungi banyak orang baik dari penduduk lokal maupun para pendatang dari wilayah sekitar, termasuk luar Jawa. Bahkan selama krisis berlangsung para pedagang mampu survive dan memiliki resistensi yang dapat diperhitungkan (compatable). Mereka menjalankan usahanya dengan lebih fleksibel, terutama dalam pemanfaatan modal dan arus barang.

Penulis berasumsi bahwa keberhasilan pedagang kain dan pakian di Tegal Gubug Cirebon selain karena faktor-faktor fleksibilitas yang terkonsentrasi pada pemanfaatan modal dan pengaturan arus barang, kompetensi individu dan nilai/norma juga turut mendorong keberhasilan usaha mereka. Kenyataan ini ditunjukkan oleh adanya sistem jual beli relasional. Sistem ini men-syaratkan adanya kemampuan undividu untuk menjalin kerjasama yang luas dengan sesama pedagang atau dengan konsumen. Menurut Perry (2000) bahwa model sistem jual beli relasional lebih didasarkan atas hubungan saling percaya (interpersonal trust).

Kemampuan pengusaha da-lam membangun kepercayaan dan komitmen yang tercermin dalam hubungan relasional pada akhirnya menjadi kunci keberhasilan usaha. Jika hubungan saling percaya telah terbentuk, mereka akan mudah membangun kerjasama baik dalam penyediaan modal usaha, penyediaan barang, maupun pendistribusiannya. Bahkan menurut Fukuyama (1995), jika para pengusaha 
menerapkan sikap saling percaya, maka mereka akan dapat menyimpan (saving) biaya pengurusan kontrak, seperti penekanan terhadap biaya transaksi, mengurangi pertikaian, dan mengurangi proses hukum jika terjadi pertikaian.

Bertolak dari penjelasan di atas, studi ini lebih diorientasikan untuk menelusuri pola terbentuknya kepercayaan di kalangan pedagang, khususnya yang bergerak pada penjualan kain dan pakaian di Tegal Gubug Cirebon. Fokus utama penelitian ini adalah: "Bagaimana para pedagang kain dan pakaian membangun kepercayaan dan sekaligus mempertahankannya sehingga dapat survive dalam melakukan bisnisnya”. Fokus tersebut selanjutnya dapat diuraikan dalam bentuk pertanyaan-pertanyaan sebagai berikut: Pertama, bagaimana para pedagang kain dan pakaian membentuk dan memelihara kepercayaan (trust) dalam usaha? Kedua, bagaimana bentuk-bentuk kepercayaan di kalangan pedagang dijalankan? Ketiga, faktor-faktor apa saja yang mempengaruhi terbentuk dan terpeliharanya kepercayaan di kalangan pedagang?

Tujuan penelitian ini adalah mengetahui latar belakang pola terbentuknya kepercayaan di ka-langan pedagang serta faktor-faktor yang mempengaruhinya. Berdasarkan tujuan di atas, ruang lingkup penelitian ini mencakup beberapa hal pokok, di antaranya adalah: Pertama, per-tukaran yang terjadi di kalangan pedagang yang memfasilitasi terbentuknya kepercayaan. Kedua, aktivitas produksi dan proses transaksi di kalangan pedagang. Ketiga, bentuk-bentuk kepercayaan (trust) yang terjadi, baik dari pedagang yang memberi kepercayaan (pedagang grosir) maupun pedagang yang diberi kepercayaan (pedagang eceran).

\section{B. Teori dan Metode Penelitian}

Misztal (1996), menjelaskan bahwa beberapa literatur sosiologi mengkonseptualisasikan kepercayaan sebagai kepemilikan individu, kepemilikan hubungan sosial, atau kepemilikan sistem sosial yang dapat diketahui dengan memperhatikan prilaku yang didasarkan pada tindakan-tindakan dan orientasi-orientasi pada tingkat individu. Menurutnya ada tiga pendekatan yang selama ini dilakukan oleh para peneliti dalam mengkaji konsep kepercayaan di masyarakat. Pendekatan pertama dilakukan dengan lebih menekankan pada perasaan, emosi, dan nilai-nilai individu. Kepercayaan pada pendekatan ini dikaitkan dengan beberapa sikap seperti mentalitas, kejujuran, loyalitas, dan kesungguh-an yang kajiannya lebih cenderung membaurkan antara kepercayaan itu 
sendiri dengan sikap seseorang secara psikologi. Pendekatan kedua adalah pendekatan yang menyatakan kepercayaan dipandang sebagai sebuah atribut kolektif (collective attribute). Dengan kata lain kepercayaan dijadikan suatu simbol dalam sistem yang dikembangkan pada institusi masyarakat. Pendekatan ketiga adalah pendekatan yang menyatakan kepercayaan sebagai social capital (modal sosial) pada komunitas-komunitas tertentu yang memiliki ikatan-ikatan ke-percayaan kuat.

Sedangkan Sztompka (1999) membagi kepercayaan kedalam 5 (lima) dimensi. Pertama adalah dari dimensi civic culture dimana kepercayaan (trust) dinyatakan sebagai sikap individu. Civic culture mengasumsikan suatu kemampuan politik yang terdistribusi secara luas dan adanya hubungan timbal balik kepercayaan (mutual trust) pada warga masyarakat. Kedua adalah dimensi civil society yang mencakup adanya hubungan kepercayaan (trust) secara horizontal di antara warga masyarakat dan hubungan vertikal terhadap intitusi publik. Ketiga adalah dari dimensi cultural capital. Dimensi cultural capital merupakan suatu kepercayaan inklusif kelompok-kelompok yang memiliki status tinggi (bigh-status group). Keempat adalah dari dimensi social capital yang menekankan adanya kerjasama di antara pihak-pihak yang terlibat. Dan kelima adalah dari dimensi nilai-nilai post materialist yang terkait dengan komunitas, solidaritas, dan keharmonisan interpersonal yang menerapkan pentingnya kepercayaan.

Dari ketiga pendekatan yang dikemukakan Misztal dan lima dimensi yang dinyatakan Sztompka, penelitian ini diarahkan pada pendekatan kepercayaan sebagai social capital. Dengan mengikuti kepercayaan dari pendekatan social capital, dapat dikatakan bahwa konsep kepercayaan yang memadai sebagai suatu gagasan sosiologi yang bertujuan untuk menjembatani tingkat analisis personal dan sistem, harus melihat kepercayaan sebagai suatu mekanisme sosial, yakni sebuah pola penyebab khusus yang dapat dikenali setelah kejadian. Studi kepercayaan sebagai suatu mekanis-me sosial mencakup penjelasan tindakan-tindakan masyarakat melalui motivasi dan kepercayaan. Untuk menumbuhkembangkan motivasi, maka harus ada keyakinan dari diri seseorang untuk mempercayai seseorang.

Karena itu, definisi yang lebih mendekati kepercayaan sebagai manifestasi dari social capital adalah seperti yang diungkapkan oleh Francis Fukuyama: "Trust is the expectation that arises within a community of regular, honest, and cooperative behaviour, based on commonly shared norms, on the part of other member of that community." (Fukuyama,1995). 
Dari definisi yang dikemukakan Fukuyama tersebut nampak bahwa yang hendak ditonjolkan pada kepercayaan adalah norma-norma yang dimiliki oleh suatu komunitas. Makna kepercayaan dari definisi ini merupakan by product yang sangat penting bagi norma-norma sosial kooperatif yang memunculkan social capital. Jika komunitas yang bekerjasama dapat diandalkan untuk tetap menjaga komitmen, saling tolong menolong, dan menjauhi prilaku oportunistik, maka kelompok akan terbentuk secara cepat, dan kelompok yang terbentuk itu akan mampu mencapai tujuan-tujuan bersama secara lebih efesien yang merupakan tujuan dari social capital.

Untuk mengukur tingkat keberhasilan trust dalam suatu kerjasama, Fukuyama mengajukan konsep radius of trust. Menurut Fukuyama (2002) bahwa konsep radius of trust meniscayakan adanya kriteria keberhasilan suatu kerjasama sangat dipengaruhi oleh besar kecilnya kepercayaan yang terbangun di antara pihak-pihak yang melakukan kerjasama, baik kerjasama atas seleksi kerabat maupun kerjasama atas non-kerabat. Kerjasama akan berhasil bertahan lama jika di dalamnya terbangun derajat kepercayaan (radius of trust) tinggi. Yaitu, norma-norma kooperatif seperti kejujuran dan kesediaan untuk menolong yang bisa dibagi di antara anggotanya. Sebaliknya ikatan akan mudah hancur bahkan tidak terbentuk sama sekali apabila derajat kepercayaannya (radius of trust) rendah. Kepecayaan rendah ditandai dengan sikap mementingkan individu dan saling curiga. Dan tindakan seperti ini dapat dikatakan sebagai penyimpangan sosial (ipso facto) yang mencerminkan kurangnya social capital.

Adapun Coleman (1999) menyatakan bahwa kerjasama atas kepercayaan tidak lepas dari unsur kekeluargaan/kekerabatan dan non-kekeluargaan/kekerabatan. Menurut-nya, sebagaimana mengutip Porath, bahwa dalam dalam sistem pertukaran ekonomi terdapat F-Connection. F-Connection adalah suatu bentuk hubungan yang dibangun di antara Families (keluarga), Friends (teman), dan Firms (perusahaan). Masingmasing bentuk organisasi sosial ini dapat saling mempengaruhi antara satu dengan lainnya.

Beberapa studi menunjukkan bahwa dalam tindakan ekonomi, kepercayaan memiliki peran yang signifikan untuk memelihara kerjasama di antara pihak-pihak yang terlibat. Kepercayaan menjadi kata kunci bagi para pedagang di pasar agar dalam menjalin hubungan dengan pedagang lainnya dapat bertahan lama dan bahkan lebih 
berkembang. Sztompka (1999), menjelaskan bahwa kajian trust secara kronologis dapat dilacak mulai dari Luhman. Penjelasannya dapat dirangkum pada keterangan berikut:

1. Pada tahun 1979 Niklas Luhman mempublikasikan suatu analisis trust yang dikaitkan dengan kompleksitas, ketidaktentuan dan resiko-resiko yang mencirikan masyarakat kontemporer. Untuk kali pertama, ada suatu anggapan bahwa trust bukan merupakan suatu tipe dari masyarakat tradisional, tetapi sebaliknya, ia mendapat posisi yang penting dalam pembangunan sosial modern, yang benar-benar di-perlukan pada fase modernitas sekarang ini.

2. Pada tahun 1984 Shmuel Eisenstadt dan Louis Roniger menemukan trust sebagai suatu core dalam hubungan patron-client. Dalam hubungan ini trust sekaligus dapat merekatkan hubungan yang dibangun di antara patron dan client.

3. Pada tahun 1998 Diego Gambetta mengkaitkan trust dengan berbagai setting, termasuk pada komunitas eksklusif seperti mafia. Trust tidak hanya diterapkan pada tindakan positif, namun juga dapat diterapkan pada tidakan negatif.

4. Pada tahun 1990 James Coleman memberikan model untuk menganalisis trust sebagai suatu transaksi yang rasional, dalam kerangka teori pilihan rasional. Selanjutnya model demikian diikuti oleh sejumlah kontributor pada abad ke-19 seperti Rusell Hardin yang memperluas kerangka pilihan rasional dengan analisis distrust.

5. Kemudian Anthony Giddens baik secara individu maupun bersama-sama dengan rekannya Ulrich Beck dan Scott Lash mengkaji trust sebagai gambaran karakter-istik dari masyarakat modern belakangan ini.

6. Pada tahun 1995 Francis Fukuyama memberikan suatu gambaran secara komprehensif mengenai kepercayaan sebagai sesuatu yang sangat penting dalam sistem ekonomi. Kepercayaan yang ada pada norma-norma informal sangat besar mengurangi apa yang disebut oleh para ekonom sebagai biaya transaksi (transaction costs), seperti biaya pemantauan, kontrak, keputusan, dan pelak-sanaan kesepakatan formal.

7. Pada tahun 1997 Adam Seligman mempresentasikan suatu pan-dangan kepercayaan sebagai fenomena modern yang ber-hubungan dengan pembagian kerja (division of labor), perbedaan dan pluralisasi peranan, dan konsekuensi intimidasi dan negosiasi dari harapan-harapan peranan. 
Penelitian ini menggunakan pendekatan kualitatif, yaitu pendekatan yang diarahkan untuk mendapatkan data deskriptif yang memadai dari permasalahan penelitian ini. Metode yang digunakan adalah mengkombinasikan beberapa metode, di antaranya: Pertama, wawancara mendalam (indepth interview). Khusus untuk wawancara mendalam dilakukan dengan metode snowball, yaitu metode pengumpulan data dengan cara menanyakan siapa yang memiliki informasi mengenai data yang dimaksud dari satu informan ke informan lainnya sehingga data dapat terkumpul. Wawancara mendalam dilakukan untuk mengumpulkan informasi tentang sikap, tindakan dan pola hubungan para pedagang di Tegal Gubug yang menunjukkan terbentuk dan terpeliharanya kepercayaan. Pada kegiatan ini, peneliti melakukan penggalian informasi yang mendalam yang dilakukan dengan me-wawancarai sejumlah informan sesuai data yang diperlukan dan selanjutnya memahami data untuk melakukan penyimpulan sementara. Dengan demikian, hasil wawancara bermanfaat untuk membantu proses pengecekan, konfirmasi dan validitas data yang diperoleh.

Kedua, studi dokumentasi. Studi dokumentasi pada penelitian ini dilakukan dengan menganalisis dan menginterpretasi terhadap dokumen yang terkait dengan masalah penelitian. Dokumen yang dikaji meliputi: (1) data dari pengelola pasar baik yang terkait dengan retribusi para pedagang maupun hal-hal lainnya (2) data yang diperoleh dari buku, jurnal, laporan, dan majalah yang mengarah pada masalah penelitian.dan observasi.

Ketiga, observasi. Pada tahapan observasi ini, peneliti bermaksud memperoleh pengalaman umum atau mengidentifikasi gambaran tentang seluruh situasi sosialekonomi di masyarakat. Gambaran umum tentang situasi sosial ekonomi ini meliputi tempat/lokasi, pelaku/para pekerja, dan kegiatan-kegiatan secara umum. Informasi ini diperoleh lewat beberapa kali pengamatan terhadap objek yang akan diteliti. Manfaat informasi ini akan sangat membantu bagi peneliti dalam melakukan penelitian.

Data-data yang telah dikumpulkan melalui metode penelitian di atas, selanjutnya diolah dan dianalisis sejak dilakukannya observasi. Data yang digunakan adalah data yang telah dilakukan pengecekan silang terhadap nara sumber/informan penelitian, se-hingga didapat data yang bisa dipertanggungjawabkan. Selanjutnya, data yang terkumpul akan diorganisasikan ke dalam kategori-sasi-kategorisasi yang akan menjadi unit dasar deskripsi. Sesudah itu, interpretasi dilakukan dengan cara memberi 
pemaknaan dari data tersebut, menjelaskan kategorisasi-kategorisasi data tersebut secara deskriptif, serta memahami keterkaitan-keterkaitan di antara data-data tersebut. Dasar dari kegiatan interpretasi ini dilengkapi dengan acuan pada konsep-konsep atau teori-teori yang terkait langsung dengan topik penelitian.

\section{Pembahasan}

\section{Nilai dan Norma Pedagang}

Pelaku utama usaha kain dan pakaian di Pasar Induk Sandang dapat dikategorikan ke dalam dua kategori, yakni: Pedagang grosir (wholesaler) dan pedagang eceran (retailer). Pedagang grosir mem-perjual-belikan barang untuk diperdagangkan kembali oleh para pembelinya yang mayoritas berasal dari para pedagang eceran, meski ada juga para pembeli dari konsumen langsung. Sedangkan pedagang eceran menjual barang dagangannya secara langsung kepada konsumen. Pertemuan antara pedagang grosir dengan pedagang eceran di Pasar Induk Sandang memiliki nilai atau norma tersendiri. Nilai yang dimaksud dalam konteks ini adalah kepercayaan atau segala sesuatu yang dianggap penting oleh pedagang. Sementara norma adalah aturan-aturan yang diberlakukan di kalangan pedagang yang terkait dengan sikap baik dan buruk, tindakan yang boleh dan tidak boleh.

Nilai-nilai (values) atau norma-norma (norms) yang muncul dan berkembang di kalangan pedagang di Pasar Induk Sandang Tegal Gubug dapat dikategorikan ke dalam dua bentuk. Pertama adalah nilai atau norma yang terkait dengan transaksi murni di pasar, dan kedua adalah nilai atau norma yang terkait dengan transaksi relasional melalui bentuk jaringan dan kerjasama. Nilai atau norma jenis pertama lebih mengarah pada adanya pertukaran (exchange) yang dilandasi oleh unsur untung rugi. Sementara nilai atau norma jenis kedua lebih mengarah pada hubungan tertentu yang bersifat sosial.

Adanya untung rugi pada transaksi murni di Pasar Induk Sandang, seperti pada kategori pertama, sangat terkait dengan sifat persaingan pasar yang menerapkan pasar saingan sempurna (perfectly competitive market). Transaksi di pasar membiarkan bagi setiap pembeli bebas menentukan dengan si penjual mana ia akan bertransaksi dan bebas pula dalam menentukan penawaran harga, baik dengan penawaran harga rendah maupun penawaran harga tinggi. Begitu pula sebaliknya, si penjual bebas menentukan penetapan harga tawar dan harga jadi. Ketentuan harga sepenuhnya ditentukan oleh 
me-kanisme penawaran dan permintaan. Tindakan perdagangan model demikian bebas dari apa yang disebut dengan perdagangan monopoli, sebab setiap orang memiliki kebebasan untuk menentukan pilihannya masing-masing, baik bagi penjual maupun bagi pembeli sehingga persaingan dirasakan sempurna.

Di Pasar Induk Sandang, aktivitas perdagangan pasar saingan sempurna menerapkan adanya sistem harga luncur (sliding price system). Sistem harga luncur memberikan pengaturan arus barang dan jasa dalam ekonomi tipe pasar. Pada sistem harga luncur tidak ada harga pasti yang ada adalah harga jadi yakni harga yang disepakati antara penjual dengan pembeli melalui transaksi. Transaksi terjadi melalui proses tawar menawar dengan mengadu kemampuan dan pengetahuannya masing-masing. Harga jadi biasanya meluncur turun ke bawah dari harga yang telah ditawarkan penjual. Si pedagang berusaha agar barang dagangannya terjual dengan harga tinggi, sebaliknya si pembeli berusaha agar barang bisa dibeli dengan harga yang relatif lebih murah.

Sementara nilai atau norma yang terkait dengan transaksi relasional mengedepankan pada urgensi jaringan dan kerjasama. Biasanya transaksi relasional hanya dilakukan di kalangan sesama pedagang saja. Para pedagang di Pasar Induk Sandang Tegal Gubug menggunakan jaringan bisnis dari ikatan-ikatan kekeluargaan (family ties) dan ikatan-ikatan kekerabatan (kinship ties). Dalam konteks ini, ikatan-ikatan kekeluargaan dan kekerabatan (family and kinship ties) dipandang sebagai modal sosial (social capital) yang berfungsi memfasilitasi jaringan dan kerjasama. Dengan demikian, mereka yang memiliki keluarga dan kerabat yang banyak lebih memungkinkan untuk dapat memperoleh akses lebih luas dibandingkan dengan mereka yang hanya memiliki keluarga dan kerabat yang sedikit. Ikatan-ikatan kekeluargaan dan kekerabatan yang ada dan digunakan dipandang sangat potensial dalam perolehan akses bisnis.

Kepemilikan ikatan kekeluar-gaan dan kekerbatan (family and kinship ties) pada dimensi ini berperan dalam mendorong bagi terbentuknya jaringan dan kerjasama pedagang di Tegal Gubug. Ini setidaknya ditunjukkan oleh kuatnya institusi keluarga dan kekerabatan dalam membentuk jaringan-jaringan dan kerjasama-kerjasama yang dihasilkan dari warisan sebelumnya (endowment). Praktek mendahulukan keluarga dan kerabat telah menjadi kebiasaan para pedagang di Tegal Gubug secara turun menurun (inherited ethical habits). Namun sebagai suatu kebiasaan jika tidak didukung oleh prasyarat lainnya, seperti kecakapan berdagang, tentu kebiasan itu tidak akan efektif 
untuk menciptakan kerjasama yang langgeng. Hal ini juga sekaligus menunjukkan bahwa akses para pedagang terhadap pembentukan jaringan dan kerjasama dipengaruhi oleh modal sosial (social capital) yang melekat di dalam (inside).

Beberapa pedagang yang diwawancarai menyatakan bahwa awal pembentukan jaringan dan kerjasama di kalangan pedagang dimulai dari ikatan-ikatan keke-luargaan dan kekerabatan. Kedua ikatan ini dianggap sangat efektif dalam mendukung usaha perdagangan mereka karena membangun relasi di antara sesama keluarga dan kerabat tidak perlu melewati fase "pengenalan karakter", sebab satu sama lain telah saling mengenal sehingga tidak perlu waktu lama untuk menjalin kerjasama. Meskipun ikatan kekeluargaan dan kekerabatan di kalangan pedagang sangat kuat, mereka masih memiliki keterbukaan (openship) terhadap masuknya pihak lain dari non-keluarga atau non-kerabat dalam menjalin kerjasama.

Kerjasama yang dibangun atas dasar non-keluarga atau non-kerabat biasanya memerlukan adanya resiprositas (hubungan yang bersifat timbal balik). Ada dua hal penting yang harus dimiliki oleh masing-masing pihak yang ingin bekerjasama dari nonkeluarga atau non-kerabat, di antaranya: Pertama, memerlukan pendekatan yang cukup lama (longterm approach to relationship) di antara pihak-pihak yang terlibat sehingga hubungan itu menjadi jelas dan bernilai, kedua, perlu adanya reputasi pada masingmasing pihak. Seseorang yang memiliki reputasi akan mendapatkan kemudahan dan pelayanan tersendiri dalam menjalankan usahanya. Sebagaimana Misztal (1996) katakan: "A good reputation in all types of business attracts customers and clients and increases a company's competitive advantegs". Reputasi yang baik akan memunculkuan harapanharapan yang jelas dari yang lainnya serta memungkinkan untuk melakukan pertukaran, baik barang maupun pelayanan-pelayanan dengan bentuk rekomendasi-rekomendasi.

Jika dibandingkan antara hubungan relasional yang memanfaat seleksi keluarga/kerabat (kin selection) dengan hubungan relasional yang menerapkan nonkerabat, terutama dalam memulai menjalin hubungan, maka yang disebut pertama jauh lebih efektif. Ikatan kekeluargaan dan kekerabatan memiliki daya ikat yang kuat bagi para pedagang dalam sistem sosial budaya. Di Pasar Induk Sandang Tegal Gubug, ikatan kekeluargaan dan kekerabatan akan semakin melekat dan sekaligus menjadi modal social (social capital) jika dukung oleh tingkat kepercayaan yang tinggi (bigh radius 
of trust). Sebaliknya kedua ikatan ini juga tidak akan berarti jika dirusak oleh tindakan yang mengarah pada terjadinya ketidakpercayaan.

Meskipun kerjasama yang dilandasi oleh ikatan kekeluargaan dan kekerabatan cukup efektif, ia kerapkali tidak bisa dipertahankan ketika kepentingan ekonomi (economy interest) tidak terpenuhi, yakni berupa kerjasama yang saling menguntungkan (mutual benefit). Bahkan bisa saja terjadi sebaliknya, kerjasama yang dilandasi oleh ikatan non-kekeluargaan dan ikatan non-kekerabatan lebih efektif jika didukung oleh adanya sikap saling mempercayai di antara pihak (interpersonal trust) yang bekerja-sama. Dengan kata lain, ikatan-ikatan kekeluargaan/kekerabatan masih sangat melekat selama masih dalam dimensi sosial seperti pembentukan relasi kerjasama, namun ketika memasuki aras kepentingan ekonomi, seperti saling memberikan keuntungan, maka yang lebih dilihat adalah tingkat kepercayaannya, bukan atas dasar ikatannya.

Pembentukan jaringan dan kerjasama, selain karena adanya faktor ikatan kekeluargaan/kekerab dan non-kekeluargan/non kekerabatan, juga dipengaruhi oleh dimensi budaya yang lebih luas dimana para pedagang beroperasi dan mentransfer nilai, sikap dan prilaku untuk membentuk sifat alami hubungan yang dibentuk. Tindakan para pedagang berkaitan dengan cara bagaimana memperoleh penghasilan nampak selalu merujuk pada ketentuan norma agama yang diyakininya. Norma halal, haram, makruh, sunah, dan mubah cukup melekat dan menjadi dasar utama dalam melegitimasi kegiatan bisnisnya. Semua aktivitas selalu dihubungkan dengan norma agama sehingga kondisi semacam ini cukup mendukung terhadap tumbuh dan berkembangnya kepercayaan. Di kalangan pedagang, dimensi budaya muncul lebih dikarenakan oleh adanya dukungan lingkungan yang berada disekitar mereka. Nilai-nilai dan budayabudaya agama yang sangat melekat bagi mereka memberikan peluang untuk menjadikannya sebagai jaringan. Budaya "kumpul" yang terkontruksi pada aktivitas keagamaan seperti Tablilan, Hadiyuan, Marbabanan, Halaqohan, dan Yasinan dapat dijadikan momentum untuk membentuk jaringan dan kerjasama.

Tampaknya yang belum dimiliki oleh para pedagang Tegal Gubug adalah sikap untuk mengembangkan bisnis secara lebih modern, misalnya seperti bisnis yang dikembangkan kaum kapitalis. Pada pedagang Tegal Gubug sebagian besar masih menggunakan cara-cara yang lazim diterapkan oleh masyarakat Jawa pada umumnya, yakni melakukan bisnis perdagangan hanya untuk memenuhi kebutuhan hidup sehari- 
hari. Sementara kemauan untuk melakukan bisnis yang lebih modern dengan pengembangan ke beberapa wilayah atau sektor belum banyak dipikirkan oleh para pedagang. Ada beberapa hal yang menjadi dasar kenapa mereka tidak mau mengembangkan yang lebih maju, karena pertama, mereka tidak memiliki kemampuan yang cukup untuk mengelola bisnis yang lebih besar, kedua, keuntungan dari hasil berdagang tidak dikembangkan untuk perluasan bisnis melainkan dialokasikan untuk membuat rumah yang bagus dan membeli barang-barang yang cukup mewah.

\section{Pola Relasi Kerjasama}

Pola relasi kerjasama yang dapat bertahan dan sekaligus sangat mendukung kelangsungan usaha pedagang di Tegal Gubug adalah pola langganan tetap. Istilah langganan tetap memiliki arti hubungan hutang-piutang jenis tertentu yang biasa disebut dengan hutang pandemen atau pengikat. Tujuan diterapkannya hutang pandemen adalah agar Si Pedagang eceran tidak dapat keluar dari kebiasaannya untuk membeli kepada pedagang grosir sebagai pemberi hutang. Sebutan langganan tetap menunjuk pada peminjam maupun pemberi pinjaman dalam hubungan hutang-piutang. Jika diperhatikan lebih mendalam maka hubungan hutang piutang model hutang pandemen tersebut mengandung pengertian pemberian kredit.

Relasi langganan tetap biasanya ditetapkan dalam jangka waktu satu tahun dengan batasan hari lebaran. Masa kredit akan diperpanjang untuk tahun berikutnya jika di antara pedagang yang mengikat langganan tetap merasa ada kecocokkan. Namun sebelum menginjak pembukaan hutang-piutang kredit pada tahun berikutnya, Si Peminjam hutang harus sudah melunasi kredit yang dihutangkan selama setahun sebelumnya sehingga jumlah hutang-nya tidak melebihi batas yang ditetapkan.

Hubungan yang sifatnya langganan tetap tumbuh dengan makan waktu lama (long time), bahkan dapat bertahun-tahun. Terjadinya langganan tetap biasanya dimulai dengan seringnya berbelanja. Setelah berjalan selama lebih dari setahun dan peminjam mendapat predikat "dapat di percaya", maka biasanya peminjam diberikan kebebasan untuk mengambil barang yang lebih besar dengan cara menghutang dan bayarnya dapat diangsur. Dengan cara demikian, pedagang akan memperoleh sampai tujuh puluh lima persen dari dari seluruh stok dagangannya. 
Ciri penting dari pola relasi langganan tetap ialah tidak adanya bunga, meskipun kredit berjangka panjang melibatkan sejumlah besar modal transaksi. Bahkan pedagang eceran dapat mengambil lagi barang dengan potongan harga dari pedagang grosir. Langganan tetap menguntungkan kedua belah pihak, baik pedagang eceran maupun pedagang grosir. Bagi pedagang grosir, keuntungan adanya langganan tetap menciptakan keter-aturan dalam sirkulasi uang serta sekaligus membuka jaringan penjualan bagi barang-barang dagangannya. Pedagang eceran yang melakukan keterlambatan pembayar-an pada waktu yang dijanjikan akan mendapatkan sanksi dengan lebih dipersulit dalam mendapatkan kredit atau barang. Memang tidak ada sanksi yang sifatnya formal dan diatur oleh perundang-undangan atau aturan tertulis lainnya, namun secara informal jika seseorang pernah melakukan kesalahan, seperti terlambat pembayaran, kecurangan, kebohongan dan sebagainya, akan sulit untuk mendapatkan kredit dikemudian hari. Setiap pedagang yang mengetahui kepribadiannya akan pikirpikir dulu saat meminjamkan uang atau memberi barang kepadanya karena dianggap memiliki reputasi yang jelek.

Reputasi bagi hubungan langganan tetap menjadi syarat dalam pendapatan kredit dan pengambilan barang. Reputasi dianggap sebagai suatu penilaian terhadap tindakan yang dilakukan seseorang yang mencerminkan penampilan (performance) kepribadiannya. Seorang pedagang yang memiliki sikap jujur, rajin, dan kreatif dianggap memiliki reputasi yang baik. Sebaliknya, seorang pedagang yang memiliki sikap kurang jujur, malas, dan kurang kreatif dianggap memiliki reputasi yang rendah. Tinggi rendahnya reputasi seseorang biasanya diketahui setelah adanya pembuktian dan penjulukkan terhadap seorang pedagang. Seperti yang terdapat di kalangan pedagang bahwa Si A adalah pedagang yang sukses dan memiliki reputasi baik karena tidak pernah curang dan suka membantu kepada pedagang lainnya. Atau juga Si B memiliki reputasi yang jelek karena telah melakukan kecurangan. Untuk mengenali apakah seseorang memiliki reputasi baik atau buruk bagi pedagang adalah sangat mudah dilakukan.

Sebagian pedagang eceran di pasar memperoleh kredit dari pemasok langganan tetap mereka, meskipun kredit yang diberikan tidak seluruhnya sama. Ada pedagang mendapatkan kredit yang besar dan ada juga pedagang mendapat kredit yang kecil. Besar kecilnya kredit ditentukan oleh tingkat reputasi yang dimiliki oleh pedagang 
eceran itu sendiri. Jika ia memiliki reputasi yang tinggi di mata pedagang grosir, maka besar kemungkinan ia akan mendapatkan kelebihan-kelebihan tertentu dalam jumlah kredit. Begitu pula sebaliknya, semakin rendah reputasinya maka semakin sedikit pula kelebihan-kelebihan dalam pemberian kreditnya.

Mekanisme perdagangan lang-ganan tetap menunjukkan adanya dimensi yang menyandarkan pada rasa saling percaya (mutual trust). Para pedagang merasa bahwa dengan hadirnya trust dalam kerjasama langganan tetap dapat menciptakan perasaan aman (secure). Mereka juga merasa bahwa dengan hadirnya trust dapat menciptakan keadilan (fair-ness) sehingga kerjasama yang saling menguntungkan (mutual benefit) dapat mereka raih. Mereka juga merasa bahwa dengan adanya trust, kerjasama menjadi lebih bernilai (valued) dan penuh harapan (expectation).

Untuk mendukung keber-jalanan trust dalam kerjasama langganan tetap, para pedagang menerapkan mekanisme kontrol melalui sanksi-sanksi. Sanksi akan diberikan bagi pihak-pihak yang melanggar ketentuan-ketentuan yang telah menjadi kesepakatan bersama. Di kalangan pedagang tidak ada sanksi formal seperti pada praktek bisnis perusahaan besar. Sanki yang berlaku biasanya hanya berupa sanksi moral berupa stigma jelek seperti "kurang dipercaya”, "tidak punya reputasi baik", dan sebagainya. Bahkan untuk sanksi moral lebih tinggi, biasanya pedagang menerapkan sanksi "boikot" terhadap pedagang yang dianggap memiliki moral yang jelek dan pernah menipu atau berlaku curang.

Pemboikotan sebenarnya tidak diputuskan secara formal misalnya melalui organisasi atau lembaga tertentu, namun ia telah menjadi kebiasan para pedagang jika sudah hilang trust. Seorang pedagang yang merasa telah ditipu atau dicurangi akan menginformasikan kepada pedagang lainnya bahwa dirinya telah ditipu dan dicurangi. Melalui komunikasi face to face seperti ini ternyata cukup efektif untuk menyebarkan informasi di kalangan pedagang. Sudah barang tentu, pihak yang menerima informasi ini akan berfikir dua kali jika berhubungan atau akan melakukan kerjasama dengan orang yang telah dicap "tidak bisa dipercaya". Sanksi pemboikotan diberlakukan juga pada jenis perdagangan yang menggunakan sistem pembayaran ngalap nyaur.

Istilah ngalap nyaur, dalam pengertian lugas, menyangkut pemberian kredit berjangka pendek: pedagang eceran dapat mengambil bahan kain dan pakaian dari para pedagang grosir dengan kredit, setelah barang-barang tersebut diperdagangkan baru 
dilakukan pembayaran kepada pedagang grosir. Dan adanya langganan tetap merupakan perangkat penyaluran kredit tanpa bunga. Hal yang menguntungkan bagi pedagang grosir dengan adanya sistem demikian adalah terdistribusinya barang-barang yang ada di gudang atau yang dimilikinya. Namun dalam proses demikian, seorang pedagang grosir harus menunggu mendapatkan keuntungannya setelah barang-barang yang dikreditkan kepada pedagang eceran terjual habis.

Pada mekanisme perdagangan ngalap-nyaur, kreditor (pedagang grosir) memberi barang sampai ke batas tetap (fixed), hutang harus dikembalikan sampai batas yang telah ditentukan. Dalam batas satu tahun tersebut terdapat suatu ikatan antara pedagang grosir dan pedagan eceran dalam bentuk-bentuk tertentu, di antaranya: pertama, pedagang eceran dapat mengambil barang (kain dan pakaian) dari pedagang grosir dengan hanya setengah harga keseluruhan atau tidak sama sekali bagi para pedagang yang telah memiliki tingkat reputasi yang tinggi. Kedua, pedagang eceran dapat mencicil jumlah hutang pengambilan barang dalam batas-batas yang disepakati bersama secara informal di antara kedua belah pihak. Pada aspek ini bisa jadi perlakuan terhadap satu pedagang ke pedagang lainnya berbeda. Bagi pedagang yang dinilai cukup sulit untuk membayar hutangnya, maka dilakukan strategi-strategi tertentu dari pedagang grosir untuk menekan agar pedagang eceran dapat membayar sesuai dengan perjanjian. Ketiga, pedagang eceran harus secara terus-menerus mengambil barang dari pedagang grosir yang menjadi langganannya.

Sedangkan ketentuan yang biasanya diterapkan oleh pedagang eceran terhadap pedagang grosir di antaranya adalah: Pertama, pedagang grosir harus dapat memberi pelayanan yang memuaskan kepada pelanggan dengan memberikan perlakuanperlakuan khusus. Kedua, pedagang grosir harus dapat menyediakan barang-barang yang dipesan oleh para pelanggan. Ketiga pedagang eceran dapat sewaktu-waktu keluar dari ikatan bisnis dengan pedagang grosir jika ia dapat melunasi panjar ikatan dalam satu tahun. Dengan kata lain, jika pelanggan merasa tida ada lagi kecocokan dengan pedagang grosir, ia dapat keluar dari ikatan langgananya dengan membayar seluruh hutang lebih cepat dari waktu yang ditentukan.

Bagi penghutang (pedagang eceran) keuntungan terbesar adalah kesempatan memperoleh persediaan barang (stock) yang lebih banyak dari yang dimungkinkan oleh modalnya sendiri, tetapi ia juga dapat menambah persediaannya pada tingkat potongan 
harga dan memperoleh pengetahuan yang akurat tentang harga-harga patok-duga (benchmark price). Bagi pedagang grosir, langganan tetap menguntungkan, karena dapat memastikan aliran uang kontan yang teratur sambil mengurangi resiko perjanjian lama.

Hubungan dagang ini di-bangun secara bertahap dalam waktu yang lama, sehingga para pedagang yang berhasil tidak hanya memerlukan ketrampilan tawarmenawar dan keahlian pasar lainnya yang menghasilkan keuntungan-keuntungan yang layak, tetapi juga ketrampilan pribadi untuk mengembangkan dan mempertahan-kan omset yang tinggi, dan para pedagang yang tidak dapat mengembangkan hubungan itu harus bekerja jauh lebih keras dan lebih lama untuk pendapatan yang jauh lebih rendah. Menurut Perry (2000), transaksi berdasarkan pasar dianggap bekerja efektif jika kondisi dasar dipenuhi, di antaranya (1) hubungan yang dapat diuji dipertahankan antara pihakpihak berdagang melalui sebuah kese-pakatan di mana kedua belah pihak bebas untuk mengundurkan diri atau mengubahnya jika mereka tidak lagi puas dengan kesepakatan awal (2) pertukaran pelayanan atau barang dapat didekripsikan dan diperkirakan secara memadai sebelum pembelian, sehingga kemungkinan pelanggaran diminimalkan dan penyelesaian hukumnya relatif sederhana (3) ada tingkat kepastian dalam kondisi pasar sedemikian rupa sehingga asumsi dimana pesanan ditempatkan tetap berlaku bedasarkan rentang waktu kesepakatan.

Secara sederhana dapat dikatakan bahwa baik pola relasi kerjasama langganan tetap maupun ngalap nyaur yang diterapkan para pedagang di Pasar Induk Sandang Tegal Gubug Cirebon, keduanya sama-sama mendasarkan pada trust. Terlebih lagi baik pada pola relasi kerjasama langganan tetap maupun ngalap nyaur tidak didasarkan atas kesepakatan legal-formal, sebab yang berlaku adalah aturan informal atas dasar kesepakatan-kesepakatan tidak tertulis, maka kepercayaan menjadi sangat urgen.

\section{Simpulan}

Bagi para pedagang di Pasar Induk Sandang Tegal Gubug Cirebon, kunci keberhasilan suatu kerjasama sangat dipengaruhi oleh rasa saling percaya (mutual trust) yang dimunculkan oleh semua pihak yang terlibat. Kelanggengan suatu kerjasama sangat dipengaruhi oleh besar kecilnya derajat kepercayaan (radius of trust) yang terbangun di antara pihak-pihak yang terlibat. Kerjasama akan mudah dilakukan dan dapat bertahan lama jika di dalamnya terbangun sebuah nilai/norma kepercayaan yang 
tinggi. Sebaliknya kerjasama akan mudah hancur bahkan tidak terbentuk sama sekali apabila di dalamnya memiliki nilai/ norma kepercayaan yang rendah. Dengan demikian tinggi rendahnya kerjasama sangat inhern dengan seberapa besar nilai/norma kepercayaan yang terbentuk di antara pihak-pihak yang terlibat dalam kerjasama.

Terbentuknya kepercayaan itu sendiri memang tidak mudah, seorang pedagang harus secara selektif memilih calon pedagang yang akan diajak kerjasama. Dan salah satu yang menjadi pilihan banyak pedagang di Pasar Induk Sandang Tegal Gubug Cirebon adalah dengan memanfaatkan ikatan-ikatan keke-luargaan (family ties) dan ikatan-ikatan kekerabatan (kinship ties). Hal ini karena membentuk relasi kerjasama di antara keluarga/ kerabat lebih efektif, sebab satu sama lain telah saling memahami kepribadian masing-masing. Meski-pun ikatan keluarga/kerabat sangat melekat dan sekaligus berperan sebagai kapital sosial pedagang dalam membentuk kerjasama usaha, sebagian besar mereka masih membuka untuk bekerjasama usaha dengan pihak lain di luar ikatan keluarga atau kerabat.

Kerjasama dengan pihak non-keluarga/non-kerabat memerlukan proses yang cukup panjang. Ada dua hal penting yang harus dimiliki oleh masing-masing pihak yang ingin bekerjasama dari non-keluarga atau non-kerabat, diantaranya: Pertama, perlu adanya pendekatan waktu yang lama (long time approach) dan, kedua, perlu adanya reputasi pada masing-masing pihak yang dilihat dari sikap dan prilaku seseorang yang ditunjukkan selama melakukan kerjasama dengan client-nya, serta adanya pengakuan dari orang lain tentang kepribadian pedagang tersebut. Reputasi yang baik tentu akan memunculkuan ekspektasi dari pihak lain serta memungkinkan untuk melakukan pertukaran, baik barang maupun pelayanan-pelayanan dengan bentuk rekomendasirekomendasi.

Pembentukan kerjasama yang dilandasi unsur rasa saling percaya baik dari ikatan keluarga/kerabat maupun non-keluarga/non-kerabat pada akhirnya memiliki derajat yang sama ketika memasuki ruang kepentingan ekonomi. Meskipun ikatan kekeluargaan/kekerabatan memiliki daya ikat yang kuat bagi para pedagang dalam sistem sosial budaya, ia akan hancur jika tidak didukung oleh tingkat kepercayaan yang tinggi (bigh radius of trust). Sebaliknya ikatan non-keluarga/non-kerabat, meski tidak memiliki daya ikat yang kuat dalam sistem sosial atau sistem budaya pedagang, namun karena didukung oleh tingkat kepercayaan yang tinggi (high radius of trust), maka akan 
ARTIKEL

memiliki posisi yang kuat dalam kerjasama. Dengan kata lain, ikatan kekeluargaan/kekerabatan memiliki tempat yang lebih baik hanya pada awal pembentukan kerjasama, namun ketika sama-sama telah terbentuk kerjasama, maka posisi keduanya adalah sama.

Sistem trust yang terbentuk di kalangan pedagang terlihat pada pola relasi langganan tetap dan ngalap nyaur. Bentuk relasi seperti ini menyandarkan pada prosedur informal melalui kesepakatan-kesepakatan yang dilakukan di antara pihak-pihak yang bekerjasama dengan melihat nilai dan norma-norma yang berlaku. Pola relasi model demikian lebih menge-depankan kepercayaan yang dimiliki oleh kedua belah pihak terhadap kesepakatan-kesepakatan yang di-buat sehingga memberikan manfaat baik pada kelangsungan usaha maupun pada pembentukan modal sosial.

Kesimpulan teori dari penelitian ini pada dasarnya berupa penguatan terhadap "kebenaran" teori yang dikemukakan Francis Fukuyama mengenai radius of trust yang meniscayakan adanya kriteria keberhasilan suatu kerjasama sangat dipengaruhi oleh besar kecilnya kepercayaan yang terbangun di antara pihak-pihak yang melakukan kerjasama tersebut. Kerjasama akan berhasil bertahan lama jika didukung oleh normanorma atau nilai-nilai yang mengandung derajat kepercaya-an tinggi. Sebaliknya, kerjasama akan mudah hancur jika norma-norma atau nilai-nilai yang mendukungnya memiliki derajat kepercayaan rendah.

Terbukti, dengan kerjasama yang dilandasi derajat kepercayaan yang tinggi, pedagang memperoleh beberapa manfaat. Keuntungan adanya trust dalam kerjasama di antaranya: Pertama, mengurangi biaya transaksi karena antara pedagang terdapat sikap saling memudahkan dalam hubungan perdagangan, seperti dalam pemesan-an, pengiriman barang, serta pembayaran. Kedua, mengurangi keperluan mengurus kontrak karena tidak perlu adanya kesepakatan-kesepakatan formal, tetapi cukup secara informal. Ketiga, munculnya kesadaran untuk saling memahami terhadap situasi yang tidak teduga dari resiko-resiko yang ditanggung. Keempat, kepercayaan dapat mengurangi pertikaian yang terkadang terjadi di kalangan pedagang.

\section{DAFTAR PUSTAKA}

Alexander, J. H. 1987. Batas Minimum Kredit Untuk Pedagang Kecil. Jurnal Prisma, Vol 16, No. 7. 
Anwar, H. (2016). PENGEMBANGAN UMKM MASYARAKAT BANDUNG. JISPO : Jurnal Ilmu Sosial Dan Ilmu Politik, 6(1), 102 - 123. doi:http://dx.doi.org/10.15575/jp.v6i1.1752

Belshaw, Cyril S. 1981. Traditional Exchange and Modern Markets, diterjemahkan oleh Soebyanto, Tukar Menukar Tradisional dan Pasar Modern. Jakarta: PT. Gramedia.

Coleman, James S. 1988. Social Capital in The Creation of Human Capital Suplement. American Journal Sociology.

Creswell, JU.W. 1994. Research Design Qualitative and Quantitative Approach. London: Sage Publication, Inc.

Damsar. 1997. Sosiologi Ekonomi. Jakarta: Rajawali Press.

Dasgupta, P. \& Ismail Serageldin (ed). 2000. Social Capital: A Multifaceted Perspective. Washington D.C: The World Bank.

Dulkiah, m. (2016). Pemanfataan Media Dalam Memahami Realitas Sosial Di Kalangan Mahasiswa UIN SGD Bandung. JISPO : Jurnal Ilmu Sosial Dan Ilmu Politik, 1(1), 12-23. doi:http://dx.doi.org/10.15575/jispo.v1i1.711

Fukuyama, F. 1995. Trust: The Social Virtues and The Creation of Prosperity. New York: A Division of Simon \& Schuster Inc.

.2001. Social Capital, Civil Society and Development. Third World Quarterly, Vol. 22, No. 1.

2000. The Great Dismption, Terjemahan, Hakekat Manusia dan Rekonstruksi Tatanan Sosial. Yogyakarta: Penerbit Qalam.

Geertz, C. 1983. Involusi Pertanian: Proses Prubahan Ekologi di Indonesia. Jakarta: Bhratara Karya Aksara.

1989. Penjaja dan Raja: Perubahan Sosial dan Modernisasi Ekonomi di Dua Kota Indonesia. Jakarta: Yayasan Obor Indonesia.

1989. Abangan, Santri, dan Priyayi. Jakarta: Pustaka Jaya.

Granavotter, M. 1998. The Economic Sociology of Firms and Entrepreneurs, dalam Alejandro Portes (ed). The Economic Sociology of Immigration: Essay on Networks, Etnicity and Entrepreneurship. New York: Russel Sage Foundation.

Hefner, Robert W. (ed). 2000. Budaya Pasar, Mayarakat dan Moralitas Dalam Kapitalisme Asia Baru. Jakarta: LP3ES.

Misztal, A. Barbara. 1996. Trust in Modern Societies. Cambridge: Polity Press.

Mufti, m. (2016). ANALISIS KRITIS TERHADAP SEKTOR PERTANIAN DI INDONESIA DALAM NEGARA KESEJAHTERAAN. JISPO : Jumal Ilmu 
ARTIKEL

\begin{tabular}{lcccc}
\hline $\begin{array}{l}\text { Sosial } \\
\text { doi:http://dx.doi.org/10.15575/jispo.v1i1.713 }\end{array}$ & Dan & 1lmu & 38-50.
\end{tabular}

Perry, Martin. 2000. Small Firm and Networks Economies. Terjemahan Budhi Sastrio. Mengembangkan Usaha Kecil dengan Memanfaatkan Berbagai Bentuk Jaringan Kerja Ekonomi. Jakarta: PT. RajaGrafindo Persada.

Portes, Alejandro. 1998. The Economic Sociology of Immigration: Essay on Networks, Etnicity and Entrepreneurship. New York: Russel Sage Foundation.

1998. Social Capital: Its Origins and Application in Modern Sociology, Annu. Rev. Social, 24.

Putnam, R. D. 1993. Making Democracy Work: Civic Trdition in Italy. USA: Princeton University Press, 1993.

1993. Social Capital and Public Life. The American Prospect, Volume 4. Issue 13.

Rahman, M.T., 2011. Glosari Teori Sosial. Bandung: Ibnu Sina Press.

Sztompka, P. 1996. Trust and Emerging Democracy. International Sociology, Vol. 1.

Weber, Max. 1958. The Protestan Ethic and The Spirit of Capitalism. New York: Charles Scribner's Sons.

World Bank's Websites “On Social Capital Fpr Development”. 